\title{
Attitudes Toward Public Sector Corruption: A Study Of University Students In Kwazulu-Natal
}

Alex van der Merwe, Durban University of Technology, South Africa Geoff Harris, Durban University of Technology, South Africa

\begin{abstract}
The aim of this article is to ascertain the perceptions of public sector corruption held by university students, drawing on a questionnaire completed by 509 second-year Durban University of Technology and University of KwaZulu-Natal economics/business studies students in mid-2010.

An overwhelming proportion of respondents regarded corruption as serious or very serious and believed that it had worsened over the previous three years. Indian respondents were more likely than Africans to regard corruption as serious and becoming worse, but a very large majority of both ethnic groups held these views. All ten scenarios presented were judged to be corrupt by the majority of respondents, although there was a wide range across the scenarios. A sizeable minority reported their willingness to engage in the behaviour presented in the scenarios. Female respondents were more likely than males to report a behaviour as corrupt and to say that they would not engage in it, while African respondents were more likely than Indian respondents to report a behaviour as corrupt and to say that they would engage in it.
\end{abstract}

This study needs to be supplemented by qualitative research in order to better understand the attitudes underlying these responses.

Keywords: Corruption; Public Sector; South Africa; University Students; Attitudes

\section{INTRODUCTION}

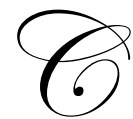

orruption has become a major concern in the South African public sector landscape, its most common forms being bribery, nepotism, misappropriation of public resources and government tender irregularities. There are also other behaviours which fall outside these illegal behaviours that can be regarded as ethically dubious. The Corruptions Perceptions Index (Transparency International, 2010) ranked South Africa 54th out of 178 countries in 2010, with a score of 4.5 out of ten, where the country ranked first is perceived to be the least corrupt and ten is 'very clean' in terms of perceived corruption. Furthermore, the perceptions of corruption are worsening over time; the South African scores in 1995 (the first year for which data were collected for the index) and 2002 were 5.62 and 4.8 , respectively.

From an economic perspective, corruption has substantial disadvantages (e.g. Cartier-Bresson, 2000, 17 18) of which four seem to be the most important. First, by distorting a country's cost structure, it reduces its allocative efficiency, competitiveness and economic growth. Second, since different people have different capacities to benefit from corruption, it increases wealth and income inequality. Third, it erodes confidence in public institutions which in turn reduces the willingness of investors, both domestic and foreign, to invest in the relevant country. Fourth, it encourages a culture of poor public service, which includes those who are inclined to act corruptly and also those inclined to take their public duties seriously, but who are discouraged from doing so by the prevailing culture. 
An important issue surrounding corruption is the extent to which, if at all, it is culturally acceptable in some societies. To Pujas and Rhodes (2001.740), for example, "What is "illegal" and "corrupt" in some societies may be considered acceptable in others. What the British would see as nepotism or shameless patronage might be considered fair or even a moral duty elsewhere. It is the perception of the practice that makes it corrupt ...'

This hypothesis was tested in a recent study by Johann Lamsdorff (2010) using data collected in the 20082009 'Voice of the People' survey which covered over 71,000 households in 66 countries. He was able to add three 'vignettes' concerning hypothetical interactions between a shopkeeper and a public official. Respondents were asked to evaluate the acceptability of the behaviours of the two players in each vignette, which differed in terms of 'how explicitly the public servant demands a favor, how clearly rules are violated, whether communication is explicit in linking a bribe/gift to the granting of a license, how direct the interaction is, and how openly the favors are exchanged' (Lamsdorff 2010.7). One of Lamsdorff's interests was to investigate whether responses varied across countries and, specifically, whether there was support for the hypothesis that people in richer Western countries had a stricter moral code - that is, they were less accepting of bribes and gift giving - than those living elsewhere. He found no support for this hypothesis.

In short, the willingness of an individual to engage in corrupt behaviour might result from their beliefs about what constitutes such behaviour. It is also possible that, even if they believed a specific behaviour as corrupt, some individuals might be more willing to act in defiance of this belief. Accordingly, the aims of this article are as follows:

- $\quad$ To discover what a sample of university students believe about the importance of corruption in South Africa, its progress over recent years and the involvement of different groups in it

- $\quad$ To discover what they believe constitutes corrupt behaviour

- $\quad$ To examine the connection between individuals' perceptions of different actions as being corrupt and their willingness to engage in them.

- $\quad$ To determine the extent to which their perceptions are influenced by factors such as age, gender, ethnicity and religious beliefs

\section{RESEARCH METHODS}

A questionnaire (available upon request from the authors) was designed and pre-tested to meet the specific aims of the research. It was applied to a sample of 509 second year Durban University of Technology and University of KwaZulu-Natal economics/business studies students in June 2010. For practical reasons, we selected four out of the six groups which made up the second-year classes at the two institutions and asked everyone present to complete the questionnaire. While not a random sample, the large numbers give us confidence that they are representative of such students at the two institutions.

The first part of the questionnaire requested demographic data and asked five questions about their attitudes toward corruption in South Africa. The second part of the questionnaire posed 10 short scenarios and asked two questions of each: 1) whether the student regarded the behaviour described as corrupt, with four options running from very corrupt to not at all corrupt, plus a category for those who were unsure, and 2) whether the student would engage in the activity, with responses running from definitely not to definitely yes, with a don't know category.

\section{RESULTS AND DISCUSSION}

Of the 509 respondents, 53.8 percent were females and 46.2 percent were males. Their mean age was 20.2 years, with 79 percent aged 19 to 21 years. In terms of ethnicity, 318 of the respondents (62.4 percent) were African and 168 (33.0 percent) were Indian, with small numbers of whites (12) and coloureds (11). As to the importance of their religious beliefs, 95 percent said that these were very important (62.2 percent) or important (32.8 percent) to them; the pilot survey indicated that asking for their particular religion or denomination was problematic and these were not sought in the main survey. 
Respondents were asked, 'How serious an issue do you think corruption is in South Africa these days?' Almost all respondents regarded it as either very serious (73.7 percent) or serious ( 23.4 percent). In response to a question asking them to compare levels of corruption now compared to three years ago, almost half (47.2 percent) thought it was much worse and 31.8 percent said that it was a bit worse.

Three questions were asked about perceptions of corruption among public servants, politicians and by the president on a scale ranging from 10 (extremely corrupt) to 0 (not at all corrupt). Public servants were given a mean score of 8.0, somewhat less than that given to politicians (8.6) and both are toward the very corrupt end of the scale. The president was better regarded with a score of 6.8 .

It was intended to cross tabulate these and later responses by gender, age, ethnicity and the importance of religion to the respondents. The narrow age range and the importance of their religious beliefs to almost all respondents meant that these two variables could not be used for cross tabulation purposes. In addition, the small number of whites and coloureds in the sample meant that ethnic comparisons had to be restricted to those between Africans and Indians.

There were no significant differences between males and females concerning these five questions but Indian respondents were significantly more likely than African respondents to regard corruption as very serious (82.6 compared with 69.2 percent) and to have become much worse (52.4 compared with 44.9 percent). A very strong majority of both groups, it should be noted, regarded it as very serious and becoming much worse. Indian respondents perceived higher corruption among politicians and public servants than did African respondents and rated the president at 8.1 on the ten-point corruption scale compared with 5.9 by African respondents.

The second part of the research involved posing 10 short scenarios (listed in the left hand column of Table 1) and asking 1) whether the student regarded the behaviour described as corrupt and 2) whether the student would engage in the activity. The results are reported in Tables 1 and 2 , respectively.

Many of the scenarios drew on cases of possible corruption reported in the South African media during 2009 and the early part of 2010. Prominent among these were reports of tender irregularities (resulting in the coining of the word 'tenderpreneurs'), of inflated claims for travel expenses by politicians, of public servants engaging in private business work during office hours and of close relations between politicians and public servants, on the one hand, and business people on the other. On reflection, it may have been better to ask, as Lamsdorff (2010) did, about the acceptability of each scenario rather than whether or not they felt it was corrupt. One reason for this is the interpretation which some students may have made of the word corruption - as something illegal, for example whereas our objective was really to discern whether or not they felt it was good or acceptable behaviour.

Table 1 indicates that all 10 scenarios were judged to be corrupt or fairly corrupt by half or more of the respondents. The average proportion of respondents who rated a scenario as very or fairly corrupt was 78.0 percent. The responses can be classified into three groups.

- Scenarios 1, 2 and 7 were rated as very corrupt or fairly corrupt by over 90 percent of respondents.

- $\quad$ Scenarios 3, 4, 5, 6 and 9 were so rated by 70-79 percent of respondents.

- $\quad$ Scenarios $(8,10)$ were so rated by 57 percent of respondents.

The first group, comprising direct monetary bribes and illegal tender decisions, represents classic corrupt behaviour whereas there is more to consider in the scenarios of the second group. Scenario 3, for example, involves a possible conflict between interfering with a job selection process and helping a relative. It is possible that respondents found the two scenarios in the last group difficult to categorise. One is theft, albeit of a low level, while the last concerns the relationship between government and business and the responses may involve judgments about the appropriateness of this relationship rather than corruption as such.

The second question - whether the student would engage in the activity - was asked to determine whether the respondent's anticipated behaviour matched their opinion concerning the corruptness of that behaviour. The term dissonance is used to describe a disconnection between beliefs and behavior. The results are presented in Table 2 . An average of 72.4 percent said that they would definitely/probably not undertake the relevant action. 
Table 1: Perceptions of the Degree of Corruption involved in the 10 Scenarios (Percent)

\begin{tabular}{|c|c|c|c|c|c|}
\hline Scenario & $\begin{array}{c}\text { Very } \\
\text { corrupt }\end{array}$ & $\begin{array}{c}\text { Fairly } \\
\text { corrupt }\end{array}$ & $\begin{array}{l}\text { A little bit } \\
\text { corrupt }\end{array}$ & $\begin{array}{c}\text { Not at all } \\
\text { corrupt }\end{array}$ & Unsure \\
\hline $\begin{array}{l}\text { 1. A businessman pays R1.2 million to a politician to } \\
\text { encourage the politician to award a major government } \\
\text { contract to him. }\end{array}$ & 86.1 & 10.6 & 1.6 & 0.4 & 1.4 \\
\hline $\begin{array}{l}\text { 2. Correct tender processes for a local government road } \\
\text { building project are not followed; rather, the contract is } \\
\text { simply given to a company, with no particular experience, } \\
\text { owned by friends of the most powerful councilors. }\end{array}$ & 79.3 & 14.8 & 2.2 & 1.0 & 2.8 \\
\hline $\begin{array}{l}\text { 3. A government official arranges for his sister to get a job } \\
\text { (for which she is qualified) in his department without having } \\
\text { to go through the normal application and selection } \\
\text { procedures. }\end{array}$ & 42.5 & 34.2 & 19.0 & 3.5 & 0.8 \\
\hline $\begin{array}{l}\text { 4. A politician makes sure that a lot of public works are } \\
\text { carried out in his own community area, which means that } \\
\text { other communities are neglected. }\end{array}$ & 47.9 & 30.3 & 15.5 & 3.5 & 2.7 \\
\hline $\begin{array}{l}\text { 5. A public servant who travels a lot as part of her work } \\
\text { submits claims for reimbursements which are far above the } \\
\text { real cost to her. }\end{array}$ & 44.4 & 33.1 & 13.8 & 2.9 & 5.7 \\
\hline $\begin{array}{l}\text { 6. A public servant spends a number of hours of his work } \\
\text { time each week running his private business activities. }\end{array}$ & 38.2 & 32.4 & 18.7 & 7.2 & 3.6 \\
\hline $\begin{array}{l}\text { 7. A traffic policeman asks a motorist for R } 100 \text { in order for } \\
\text { the motorist not to be fined for a traffic offence. }\end{array}$ & 73.4 & 20.0 & 5.2 & 1.1 & 0.2 \\
\hline $\begin{array}{l}\text { 8. A cleaner for a university earns R } 1000 \text { per month from } \\
\text { her job. She takes home cleaning fluid and other small items } \\
\text { which she sells to supplement her income - by about R30 } \\
\text { per month. }\end{array}$ & 25.8 & 31.9 & 33.3 & 7.9 & 1.1 \\
\hline $\begin{array}{l}\text { 9. Most teachers in a rural school do not come to work on } \\
\text { Fridays. }\end{array}$ & 56.1 & 21.8 & 10.6 & 4.5 & 6.9 \\
\hline $\begin{array}{l}\text { 10. A business firm makes a substantial donation to the } \\
\text { ruling political party each year. The firm doesn't have } \\
\text { particular plans but hopes that they will be regarded well by } \\
\text { the government in the future. }\end{array}$ & 30.3 & 26.8 & 15.7 & 18.1 & 9.1 \\
\hline
\end{tabular}

Table 2: Willingness to Engage in the Activity involved in the 10 Scenarios (Percent)

\begin{tabular}{|c|c|c|c|c|c|}
\hline $\begin{array}{c}\text { Your possible response in such a } \\
\text { situation }\end{array}$ & Definitely not & Probably not & Probably yes & Definitely yes & Don't know \\
\hline 1. Would you pay a politician? & 51.4 & 21.5 & 15.7 & 3.3 & 8.1 \\
\hline $\begin{array}{l}\text { 2. Would you agree to irregular } \\
\text { tendering practices? }\end{array}$ & 72.2 & 19.4 & 4.3 & 1.4 & 2.7 \\
\hline $\begin{array}{l}\text { 3. Would you get your sister a job } \\
\text { without going through the normal } \\
\text { procedures? }\end{array}$ & 36.0 & 27.0 & 27.2 & 4.7 & 5.1 \\
\hline $\begin{array}{l}\text { 4. Would you favour your own } \\
\text { community? }\end{array}$ & 45.1 & 23.9 & 19.0 & 3.4 & 8.6 \\
\hline $\begin{array}{l}\text { 5. Would you inflate your travel } \\
\text { claims? }\end{array}$ & 42.0 & 30.0 & 17.2 & 3.4 & 7.4 \\
\hline $\begin{array}{l}\text { 6. Would you run your private } \\
\text { business from work? }\end{array}$ & 38.1 & 32.2 & 19.9 & 3.8 & 6.1 \\
\hline 7. Would you ask for a bribe? & 66.5 & 18.7 & 9.2 & 3.1 & 2.5 \\
\hline $\begin{array}{l}\text { 8. Would you take small items from } \\
\text { work? }\end{array}$ & 32.0 & 28.0 & 29.0 & 6.3 & 4.7 \\
\hline $\begin{array}{l}\text { 9. Would you stay away from } \\
\text { school on Fridays? }\end{array}$ & 67.2 & 20.3 & 7.1 & 0.8 & 4.5 \\
\hline $\begin{array}{l}\text { 10. Would you donate to a political } \\
\text { party? }\end{array}$ & 34.9 & 27.4 & 20.5 & 7.3 & 9.8 \\
\hline
\end{tabular}


An interesting question is the extent to which perceptions concerning the corruptness of a particular action were reflected in perceived behaviour. That is, if respondents regarded an action as corrupt, would they still do it? In general, if individuals said that the behaviour was fairly or very corrupt, they also said that they would probably or definitely not engage in it. The average proportion of respondents who said that they would probably or definitely engage in the action was 20.7 percent, which seems to fit well with the average corruption rating (78 percent). However, it is important to match individual responses. What did those who said that the behaviour was fairly or very corrupt say about engaging in it? For four of the scenarios (1,3,5 and 8), between 15 and 21 percent of those who said the behaviour was probably/definitely corrupt also said that they would probably/definitely engage in it.

This suggests a fairly widespread willingness to engage in corrupt behaviour although it is interesting to note that the other scenario from group one (irregular tendering practices) had a very low proportion of respondents who said they would probably/definitely engage (5.5 percent). Scenario 3 indicates a tension between what might be wrong for other people but which might be justifiable to the respondent if the beneficiary was a relative. The respondents may have had personal experience with the behaviour in scenario 9 (absent teachers) and this may have influenced their own aversion to stay away in such circumstances; only 7.9 percent indicated that they would probably/definitely engage in it.

The fourth aim of the article was to examine whether gender and ethnicity influenced perceptions. Females were significantly more likely than males to regard scenario 6 (running a private business from work) as corrupt behaviour and were significantly less likely to say that they would probably or definitely engage in the behaviour outlined in six of the scenarios $-1,3,5,7,8$ and 10 (see Table 3). African and Indian students were not significantly different in their responses concerning what constituted corrupt behaviour. However, African students were significantly more likely than Indian students to say that they would probably or definitely engage in the behaviours outlined in five of the scenarios - 1, 2, 3, 4 and 8 (see Table 4).

Table 3: Perception of Activity being Corrupt and being Willing to Engage, by Gender (Percent)

\begin{tabular}{|c|c|c|c|c|}
\hline & \multicolumn{2}{|c|}{ Corrupt } & \multicolumn{2}{|c|}{ Engage } \\
\hline & Male & Female & Male & Female \\
\hline 1. Pay a politician & 97.4 & 95.9 & 26.8 & $12.4^{*}$ \\
\hline 2. Irregular tendering practices & 93.1 & 94.9 & 6.8 & 4.8 \\
\hline 3. Get your sister a job & 78.3 & 75.5 & 36.2 & $28.5 *$ \\
\hline 4. Favour your own community & 22.6 & 16.0 & 26.4 & 17.2 \\
\hline 5. Inflate your travel claims & 74.4 & 80.3 & 26.6 & $15.5 *$ \\
\hline 6. Run business from work & 62.6 & $77.4^{*}$ & 27.2 & 20.5 \\
\hline 7. Ask for a bribe & 91.3 & 95.4 & 17.0 & $8.4^{*}$ \\
\hline 8. Take small items from work & 57.8 & 57.7 & 46.1 & $35.1 *$ \\
\hline 9. Stay away from school on Fridays & 75.3 & 80.1 & 7.7 & 8.1 \\
\hline 10. Donate to political party & 55.6 & 58.4 & 33.3 & $23.2 *$ \\
\hline
\end{tabular}

Note: An asterisk means a significant chi square value between genders at the 5 percent level. Don't know and unsure respondents were omitted.

Table 4: Perception of Activity being Corrupt and being Willing to Engage, by Ethnic Group (Percent)

\begin{tabular}{|l|c|c|c|c|}
\hline \multirow{2}{*}{} & \multicolumn{2}{|c|}{ Corrupt } & \multicolumn{2}{c|}{ Engage } \\
\cline { 2 - 5 } & African & 99.4 & African & $10.8^{*}$ \\
\hline 1. Pay a politician & 97.0 & 98.1 & 8.3 & $0.6^{*}$ \\
\hline 2. Irregular tendering practices & 91.1 & 74.3 & 36.8 & $24.5^{*}$ \\
\hline 3. Get your sister a job & 76.8 & 78.4 & 27.2 & $15.6^{*}$ \\
\hline 4. Favour your own community & 78.4 & $76.6^{*}$ & 17.1 & 19.8 \\
\hline 5. Inflate your travel claims & 61.6 & 70.0 & 17.1 & 19.7 \\
\hline 6. Run business from work & 70.4 & 94.7 & 14.2 & 10.5 \\
\hline 7. Ask for a bribe & 92.5 & 53.9 & 40.9 & $28.3^{*}$ \\
\hline 8. Take small items from work & 58.1 & 71.3 & 8.6 & 7.2 \\
\hline 9. Stay away from school on Fridays & 80.2 & 56.6 & 28.8 & 26.5 \\
\hline 10. Donate to political party & 57.8 & & & 2 \\
\hline
\end{tabular}

Note: An asterisk means a significant chi square value between ethnic groups at the 5 percent level. Don't know and unsure respondents were omitted. 


\section{SUMMARY AND CONCLUSION}

The main results of the research can be summarized as follows:

- $\quad$ An overwhelming proportion of respondents regarded corruption as 'serious or very serious' and believed that it had worsened over the previous three years. Indian respondents were more likely than Africans to regard corruption as 'serious and becoming worse' and they perceived higher levels of corruption among politicians and public servants. All of the ten scenarios presented were judged to be corrupt by the majority of respondents, although there was wide variation across the scenarios. In general, if individuals said that the behaviour was corrupt, they also said that they would not engage in it. For four of the scenarios, however, 15 percent or more of those respondents who said that the behaviour was corrupt also said that they would engage in it.

- $\quad$ Female respondents were more likely than males to report a behaviour as corrupt and to say that they would not engage in it. Africans were more likely than Indians to report a behaviour as corrupt and yet say that they would engage in it.

The dissonance which the second conclusion identifies is puzzling at first sight but similar results have been found elsewhere. For example, Miller's (2006) study in four post-communist European countries found that the vast majority of citizens and public officials condemned bribery, but significant minorities (and majorities in some contexts) admitted paying bribes when asked and accepting bribes when they were offered. That is, external pressures outweighed inner values, resulting in officials responding to temptation and citizens to extortion. Miller interprets this (2006. 371) to mean that people are best viewed as corruptible rather than as corrupt.

A broader explanation in the African context is 'politics as consumption' - a widely-held attitude that achieving public or political office provides a legitimate opportunity for personal enrichment. It is common for individuals and political parties, quite soon after taking office, to succumb to the temptation of large sums of money being offered for favours and, in time, to come to expect and demand such bribes. The recent book "It's our turn to eat: the story of a Kenyan whistleblower" (Wrong, 2009) illustrates this for Kenya. From independence in 1963 until 1978, the country was led by Jomo Kenyatta, whose government favoured his Kikuyu tribe and whose politicians and public servants practiced personal enrichment. In 1978, Daniel arap Moi, a Kalenjin, replaced Kenyatta and the benefits favoured his tribe and his politicians and public servants practiced personal enrichment. In 2002, after a short period of condemning the corruption of the Moi government and vowing to be different, it was the turn of Mwai Kibaki and his Kikuyu government to 'eat'. The tribal aspect is much less relevant in South Africa, but the use of public and political offices as vehicles for personal enrichment is becoming increasingly entrenched.

The quantitative findings reported in this article need to be supplemented with in-depth qualitative research in order to better understand the many subtleties which surround the issue. A series of focus group discussions with a sample of the respondents is being planned.

\section{AUTHOR INFORMATION}

Alex van der Merwe, Senior Lecturer, Department of Public Management \& Economics, Durban University of Technology, Pietermaritzburg, South Africa. E-mail: alexvdm@dut.ac.za

Geoff Harris, Professor, International Centre for Nonviolence, Durban University of Technology, Durban, South Africa. E-mail: harrisg1@ukzn.ac.za. Corresponding author.

\section{REFERENCES}

1. Cartier-Bresson, J., 2000, The causes and consequences of corruption: economic analyses and lessons learnt, in Organisation for Economic Co-operation and Development, No longer business as usual: fighting bribery and corruption, Paris: OECD, 11-27.

2. Lambsdorff, J., 2010, Who accepts bribery? Evidence from a global household survey, Wirtschaftwissenschaftliche Fakulttat, Universitat Passau, Discussion Paper No. V-61-10. 
3. Miller, W., 2006, Corruption and corruptibility, World Development, 34(2), 371-380.

4. Pujas, S. and Rhodes, M., 2002, in A. Heidenheimer and M. Johnston (eds.), Political corruptionconcepts and contexts, New Brunswick: Transaction Publishers, 739-760.

5. Transparency International, 2010, Corruption perceptions index 2010, http://www.transparency.org/policy_research/surveys_indices/cpi. Accessed April 15, 2011.

6. Wrong, M., 2009, It's our turn to eat: the story of a Kenyan whistleblower, New York: Harper. 


\section{NOTES}

